\title{
Tell el-Murra (Northeastern Nile Delta Survey): preliminary report on research in 2014-2015
}

\author{
Mariusz A. Jucha, 'Grzegorz Bąk-Pryc, \\ Natalia Małecka-Drozd ${ }^{3}$ and Magdalena Kazimierczak \\ 1,2,3,4 Institute of Archaeology, Jagiellonian University in Kraków
}

\begin{abstract}
The paper deals with the results of excavation in 2014 and 2015 at the Tell el-Murra site in the northeastern part of the Nile Delta. The investigations covered a settlement mostly from the Old Kingdom period found in trench T5; more specifically, the investigated features seem primarily connected with food production. Settlement remains from the Naqada III-possibly Early Dynastic and Protodynastic(?) periods were also explored in trench S3B. Continued research on the Early Dynastic cemetery in trench S3 yielded 16 more graves, including simple pit burials and chamber graves. In several cases bodies had been placed in pottery coffins. The presence of several mud-brick walls, possibly associated with older settlement structures, was also confirmed within the lattermost trench. Altogether the research provided new data on the settlement architecture, site development processes and burial customs invoked in the beginnings of the Egyptian state.
\end{abstract}

Keywords: Tell el-Murra, Egypt, Nile Delta, Predynastic, Early Dynastic, Old Kingdom, cemetery, settlement

Two seasons of archaeological excavation were carried out at the site of Tell elMurra in the northeastern part of the Nile Delta, excavated since 2008 (Jucha 2009; 2010; Jucha et al. 2013: Fig. 1; 2016; Jucha and Bąk-Pryc 2017; Jucha, BąkPryc, and Czarnowicz 2014; Jucha, BąkPryc, and Małecka-Drozd 2015; Jucha and Buszek 2011). In 2014 and 2015, trenches T5 in the northeastern and S3 and S3B in the southwestern part of the tell were explored (Jucha, Bąk-Pryc, and
Małecka-Drozd 2015: Fig. 1). Mostly Old Kingdom settlement remains were the focus in the first area (T5), although the upper levels of structures possibly of Early Dynastic chronology were also reached. Early Dynastic graves were explored in trench $S 3$, which also revealed the remains of a possible settlement from an earlier part of the Naqada III period. Evidence of a settlement of similar chronology has also been found in trench S3B. 


\section{TRENCH T5}

Research in the northeastern part of the tell was a continuation of the exploration of test trench S1 in 2010 (Jucha et al. 2013: 108-110) and trench T5 in 2013 (Jucha, Bąk-Pryc, and Małecka-Drozd 2015: 208-213). In 2014, the entire area of trench T5 $(15 \mathrm{~m}$ by $21 \mathrm{~m})$ was excavated (Levels 12 to 17, altitudes respectively $6.50 \mathrm{~m}$ and $6.00 \mathrm{~m}$ ). In the following season, exploration of the southern part of the trench was restricted (are R8, square S8AC), most of the work being in the northern part of the trench (are R7, square $\mathrm{S} 7 \mathrm{AC}$, southern ends of squares
R6CD and S6C), where settlement remains from Level 17 (altitude $6.00 \mathrm{~m}$ ) to Level 25 (altitude $5.20 \mathrm{~m}$ ) were excavated. The archaeological material confirmed the Old Kingdom chronology of the latest phase of site habitation, established for this part of the tell during earlier seasons (Jucha, Bąk-Pryc, and Czarnowicz 2014: 150; Jucha et al. 2013: 108-110; Jucha, Bąk-Pryc, and Małecka-Drozd 2015: 208213). Moreover, the lowest levels explored in the northern part of the trench during the 2015 season also provided material dated roughly to the onset of the Old

Team

Dates of work: 7 March-14 April 2014 and 17 February-29 March 2015

Co-Directors: Dr. Mariusz A. Jucha (Institute of Archaeology, Jagiellonian University in Kraków; 2014, 2015); Grzegorz Bąk-Pryc, archaeologist (PhD candidate, Institute of Archaeology, Jagiellonian University in Kraków; 2014, 2015)

SCA representatives: Abd el Baset Ismail Mohamed Khaery (Tanis SCA Inspectorate; 2014), Mohamed Al-Sayed Mohamedien Mohamed and Amira Hussein Ibrahim Elsaid (Tanis SCA Inspectorate; 2015)

Archaeologists: Prof. Krzysztof M. Ciałowicz (Institute of Archaeology, Jagiellonian University in Kraków; 2014), Natalia Małecka-Drozd (PhD candidate, Institute of Archaeology, Jagiellonian University in Kraków; 2014, 2015), Dr. Piotr Kołodziejczyk (Institute of Archaeology, Jagiellonian University in Kraków; 2014)

Archaeologist and ceramologist: Magdalena Kazimierczak (PhD candidate, Institute of Archaeology, Jagiellonian University in Kraków; 2014, 2015)

Archaeologist and ceramic analyst: Mary F. Ownby (University of Arizona; 2015)

Documentalists: Aleksandra Siciak (2014, 2015), Adelina Szczerbińska (2014), Konrad Grzyb (2014, 2015), Jakub Niebylski (2014, 2015), Katarzyna Lajs (2015), Ewa Glimos (2015), Mikołaj Maciejewski (2015), Monika Kozubal (2015), Ewa Rydzewska (2015) (all Institute of Archaeology, Jagiellonian University in Kraków)

Anthropologist: Katarzyna Mądrzyk, Barbara Woźniak (both PhD candidates, Department of Anthropology, Jagiellonian University in Kraków; 2015)

Archaeozoologists: Dr. Renata Abłamowicz (Silesian Museum, Katowice; 2015)

Photographer: Ewa Kuciewicz ( $\mathrm{PhD}$ candidate, Institute of Archaeology, Jagiellonian University in Kraków; 2015)

\section{Acknowledgments}

The article is the result of implementing a project financed by funds from the National Science Centre, Poland, allocated on the basis of the decision number DEC-2013/09/B/HS3/03588. 
Kingdom, possibly even the very end of the Early Dynastic period, although structures recognized there were not explored completely before the end of the 2015 season.

\section{EARLY DYNASTIC/ OLD KINGDOM}

Building in the west of the trench In the western part of the trench the upper levels of a building, which started to be recorded at Level 20 (altitude $5.70 \mathrm{~m}$ ), went down to Level 25 (altitude $5.20 \mathrm{~m}$ ).
The west wall (T5-203) of this eastern part of a house crossed a perpendicular wall (T5-210) [Fig. 1]. Also exposed was a short wall T5-237, running perpendicularly to wall T5-203, terminating in a kind of a posthole with a mud encasement at the eastern end. The eastern parts of compartments T5-211 and T5-227 were also traced. Remains of a brick silo (T5-229A/T5-229B) were found at the northern end of the latter. The most characteristic feature of the southern compartment (T5-211) was another brick

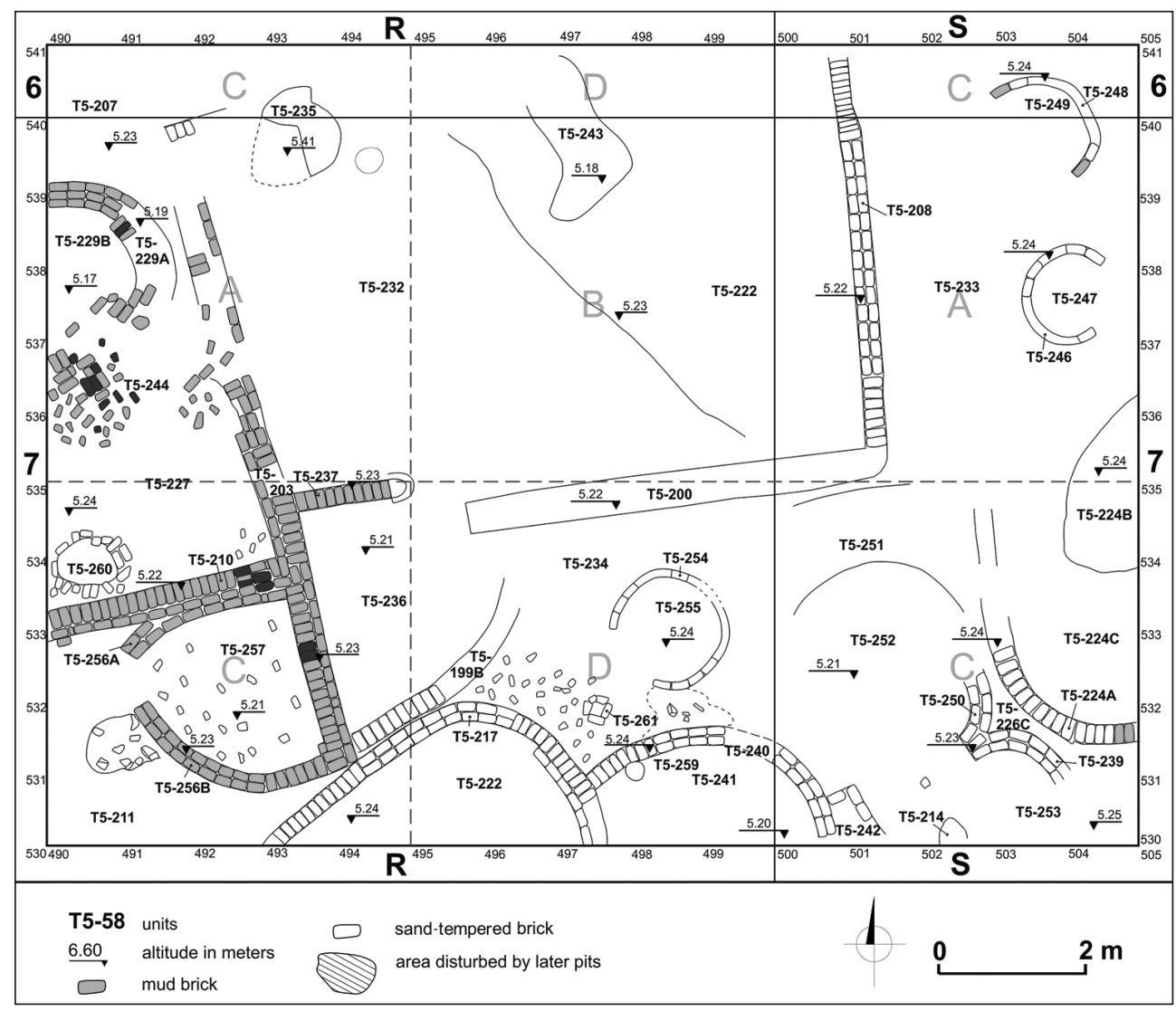

Fig. 1. Trench T5. Settlement structures in the northern part of the trench. Levels 23-25 (Tell el-Murra Expedition Archive/digitizing N. Matecka-Drozd) 
silo (T5-256A/T5-256B/T5-257), built into the corner formed by walls T5-203 and T5-210. An opening visible in its western side is typical of granaries (Badawy 1954: 58-59; Roik 1988: 186-191, Figs 279-304) and was used to access the grain stored inside. The walls of the described building were erected of very bright greyish mud bricks and yellowish sand-tempered bricks, although examples of unbaked but almost black bricks occurred as well.

The structure continues below Level 25 , hence its chronology could not be established definitively in 2015. Pottery shapes from the uppermost levels represent forms known already from the latest Early Dynastic period as well as from the onset of the Old Kingdom.

\section{Enclosure wall}

Part of another structure made of sandtempered bricks was recognized in the middle of the northern part of the trench, east of the building described above. Only its southwestern corner, formed by walls T5-200 and T5-208, could be seen during the described seasons throughout Levels 19-25 (altitude $5.80 \mathrm{~m}$ to $5.20 \mathrm{~m}$ ). The orientation of the walls was practically E-W (T5-200) and N-S (T5-208), the latter wall running under the unexplored area to the north [see Fig. 1]. The extent of this structure toward the west was not clear and its foundation not reached during the reported seasons. Pottery forms from the very beginning of the Old Kingdom were recorded from the uppermost levels within the area surrounded by these two walls, while the bottom levels yielded more forms from the later part of the Early Dynastic period. The walls do not appear to have been an original element of the later structures, but it does seem that their upper parts were to be seen and

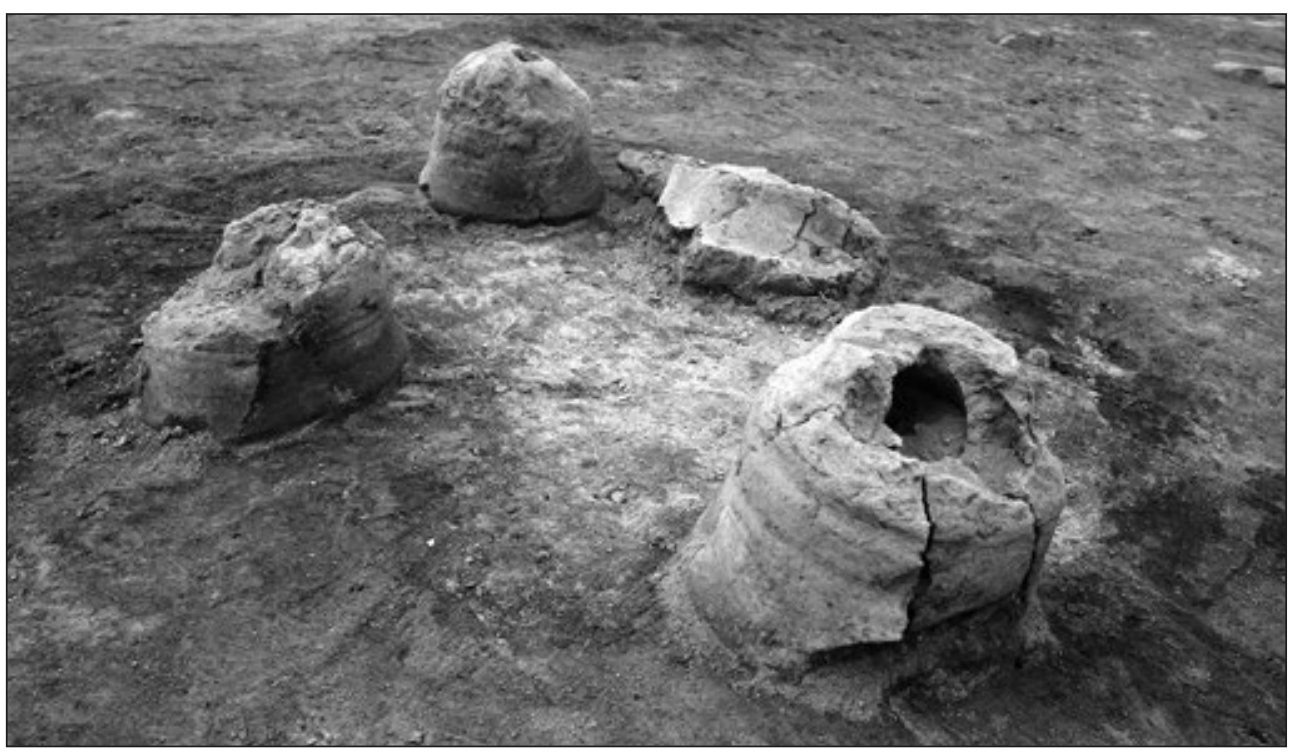

Fig. 2. Trench T5. Bread moulds in a shallow pit in an ash layer. Level 21, onset of the Old Kingdom (Third Dynasty?) (Tell el-Murra Expedition Archive/photo E. Kuciewicz) 
perhaps even served some function during the later occupation of this area (see the bakery below). Layers of reddish soil (T5-228, T5-232) and two fireplaces (T5-235 and T5-243) were recognized inside the area bordered by the said walls. A bowl was found in situ next to one of the fireplaces (T5-235), which may suggest cooking activities of some kind taking place here.

\section{Area with silos(?)}

Four quite large brick walls of arched outline (T5-199B, T5-217, T5-240, T5-224A) and two smaller ones (T5-239, T5-250), all partly connected to each other, were recognized in Levels 23-25 (altitude $5.40-5.20 \mathrm{~m}$ ), to the south and southeast of the presumed enclosure wall [see Fig. 1]. Between the arches and slightly north of them were a few small circular features (about 1-2 $\mathrm{m}$ in diameter), probably silos (T5-246, T5-248, T5-254). Their chronology, as well as layout and function, could not be determined more precisely as they continued below the last level explored in 2015. Similarities to structures discovered in Mendes (Adams 2009: Fig. 20) suggested a tentative reconstruction of the area as partly open space related to food storage and processing/production.

\section{Bakery(?)}

Structures that do not form any recognizable buildings or rooms occupied the area overlying most of the abovedescribed structures, perhaps even using to some extent the still standing ruins. The first remains of the said structures were observed through Levels 18-20 and continued down to Level 23 (altitude $5.40 \mathrm{~m}$ ). They are associated with the onset of the Old Kingdom (probably Third Dynasty), but their nature is uncertain. At least two poorly preserved, circular silo facilities as well as fragments of walls were observed in the eastern part of the trench. The most telling are the numbers of bread moulds positioned upside down in a shallow pit in the ash layer (T5-178) [Fig. 2; see Fig. 5:3]. A large pottery vat found to the north of them seems also to be related to the said levels. Several smaller vats or large bowls were discovered in the area. Furthermore, traces of mud circles, in which vessels could have been embedded, led to the assumption that more vessels were present in the vicinity. Moreover, there were few Meidum bowls, much less compared to younger levels (see below).

The nature of these finds suggest a production area related to a bakery (see Lehner 1993: 60-66; 1994: 26-29), in which at least some of the activities seem to have been carried out in the open space with the excavated vats and bowls being used as vessels for preparing the bread dough.

To the west of the structures was a $0.20-0.30 \mathrm{~m}$ thick layer (T5-169; Levels $18-20$, altitude $5.90-5.70 \mathrm{~m})$ cotaining large quantities of fragmented pottery, mostly bread moulds. Next to them, in the western and southwestern parts of square $\mathrm{R} 7 \mathrm{AC}$, there was a layer of greasy, dark grey mud (T5-190) of similar thickness, overlying the earlier settlement remains.

\section{Pottery}

The pottery assemblage collected from Levels 17-24 represents forms related to the onset of the Old Kingdom, as well as those known already during the later part of Early Dynastic period. The repertoire of forms changed over these few levels 
with certain types becoming rare or even disappearing completely. Some new forms appeared or became more frequent; among others, Meidum bowls increased in number in levels of later date. Fine wares comprised mostly bowls with convex sides and simple or lip-rims, plates and, rarely, low-stands [see Fig. 6:23]. Meanwhile, the assemblage was dominated by coarse wares, including bread moulds, vats and big bowls with thickened rims, beer jars with collars or simple rims, trays, bowls with internal ledges. Additionally, the assemblage included a miniature drop-shaped jar [Fig. 6:20] belonging to rough ware, a miniature bowl [Fig. 6:21], and a sherd with painted decoration [Fig. 6:22]. The assemblage from the lowermost level explored during the 2015 season (Level 24, altitude 5.30-5.20 m) was even less varied, comprising mostly bowls with an angular inner edge of the rim, jars with a lip-rim, bread moulds with a thickened internal part of the rim, and red-coated plates, whereas Meidum bowls, beer jars with a collar, and bowls with an internal ledge were absent.

The gradual changes observable in the pottery assemblage are significant. The absence of fine Meidum bowls from the lowermost levels explored, coupled with more of other forms related to economic and domestic activities (such as bread moulds and plates) suggest a strictly economic character of this area, which may have included storage and distribution functions.

\section{EARLY OLD KINGDOM \\ Settlement structures}

Most of the structures explored (during the described seasons) were dated to the earlier part of the Old Kingdom (Third and Fourth Dynasties). Almost the entire area of the trench was occupied by the remains of a large building complex [Figs 3,4]. Fragments of two other separate buildings were visible in the southern part. Several rebuilding stages and changes of layout were observed. The walls (about $0.25 \mathrm{~m}$, up to $0.60 \mathrm{~m}$ wide) were built of mainly bright, sand-tempered bricks of conventional size (about $12-15$ by $25-$ $30 \mathrm{~cm}$ ), although mud bricks occurred as well. Occasionally, narrow (about 7-10 cm wide) sand-tempered bricks and mud bricks were used. These were probably ordinary bricks but laid on their sides. They may have been used, at least in some cases, to construct brick thresholds.

\section{Large building complex}

The most complete and best recognized are the remains of a building complex, the later stages of which were first noted in 2013 (Jucha, Bąk-Pryc, and Małecka-Drozd 2015: 209-212, Fig. 11). It was aligned NW-SE and comprised rectangular rooms, courtyards and corridors.

In the northern part of the trench, two parallel walls touching each other, western T5-56A and eastern T5-56B, formed the borders of adjacent compartments. The west wall was possibly added slightly later [see Fig. 4] as it was not visible on the lower levels [see Fig. 3]. The area to the east, enclosed by walls T5-56B and T5-13, was subdivided into several compartments, e.g., T5-84, T5-85, T5-88, and T5-155 [see Fig. 3]. Some differences in layout were observed between subsequent levels there as well. Yet another compartment (T5-90), limited by walls T5-89 and T5-119A/T5$119 \mathrm{~B}$, was distinguished to their west.

Several additional compartments (e.g., T5-93, T5-97/T5-98, T5-112) were also easily recognizable to the south of this 
area. Others, however, especially to the south of wall T5-13, had less clear divisions and borders. The only visible set were poorly preserved walls (T5-159, T5-156, T5-109, T5-115), which enclosed possibly several small rooms or passages (T5-157, T5-118, T5-158, T5-160) [see Fig. 3]. Some gaps in the lines of the walls could have served as doorways between the rooms. However, the overall interpretation was hindered by a number of animal burrows disturbing the area. Mostly the lower parts of walls were preserved, but in the upper levels, the whole area (T5-58) was almost empty [see Fig. 4]. It is difficult to say whether this was due to the poor condition of the walls or intentional levelling under an open-air space.

The further part of the building complex, located in the southern part of the trench, had a clearer arrangement of compartments, corridors and entrances. The remains exposed there also provided better evidence for changes in the general layout between the older [see Fig. 3] and younger [see Fig. 4] subphases.

An older stage of the building was recognized mainly in its eastern part [see Fig. 3]. Its courtyard (T5-133A/T5133B) was surrounded by walls: T5-21, T5-22, T5-131, T5-132. An additional compartment, T5-57B, adjoined the courtyard to the north. The presence of a limestone yoke in its northeastern corner, close to wall $\mathrm{T} 5-8$, points to the location of a doorway there. Two quite small compartments (T5-13) and T5-141) were discovered west of wall T5-131 [Fig. 3]. Their eastern and western borders were partly disturbed by later walls T5-11 and T5-29 [see Fig. 4]. Southwest of these compartments, a room or courtyard (T5-137), limited to the west by wall T5-143, was distinguished [Fig. 3]. Within this space, traces of a few small, rounded structures (T5-144A/T5-144B, T5-145, T5-146, T5-147, T5-148A/ T5-148B) were revealed, in two cases with mud encasements (T5-144A and T5-148B). Such encasements were either a kind of potstand or, at least in a few cases, post holes. The latter indicate that the area could have been sheltered with at least a part-roof constructed of light materials. Scarce remains of walls related possibly to a later subphase (i.e., T5-38) were recognized to the west and northwest of wall T5-143 and so were facilities connected with both the later and earlier sub-phases (i.e., T5-67 and T5-76 forming a corner). Two large ceramic vats were located in the vicinity. However, their association to the described subphase is uncertain, since their bottom parts were situated around $40 \mathrm{~cm}$ (Level 21) below the lowermost level (17) explored in that part of the trench in 2014.

In the younger stage [Fig. 4], two better preserved main sections divided by a narrow corridor (T5-40D) were still recognized, although the structure was partly disturbed by storage pits of the late Old Kingdom (Jucha et al. 2016: Fig. 24; Jucha, Bąk-Pryc, and Małecka-Drozd 2015: 209213, Fig. 11). A limestone threshold in the northern part of the corridor indicated this to be the main entrance to the building. It is impossible to determine whether entrances to adjoining areas on either side of the corridor existed in its southern end, which was disturbed by one of the late Old Kingdom pits (T5-50/T5-63). The area to the northeast of the corridor had a rectangular shape (T5-32/T5-57). It was surrounded by walls T5-8, T5-11, T5-21, 


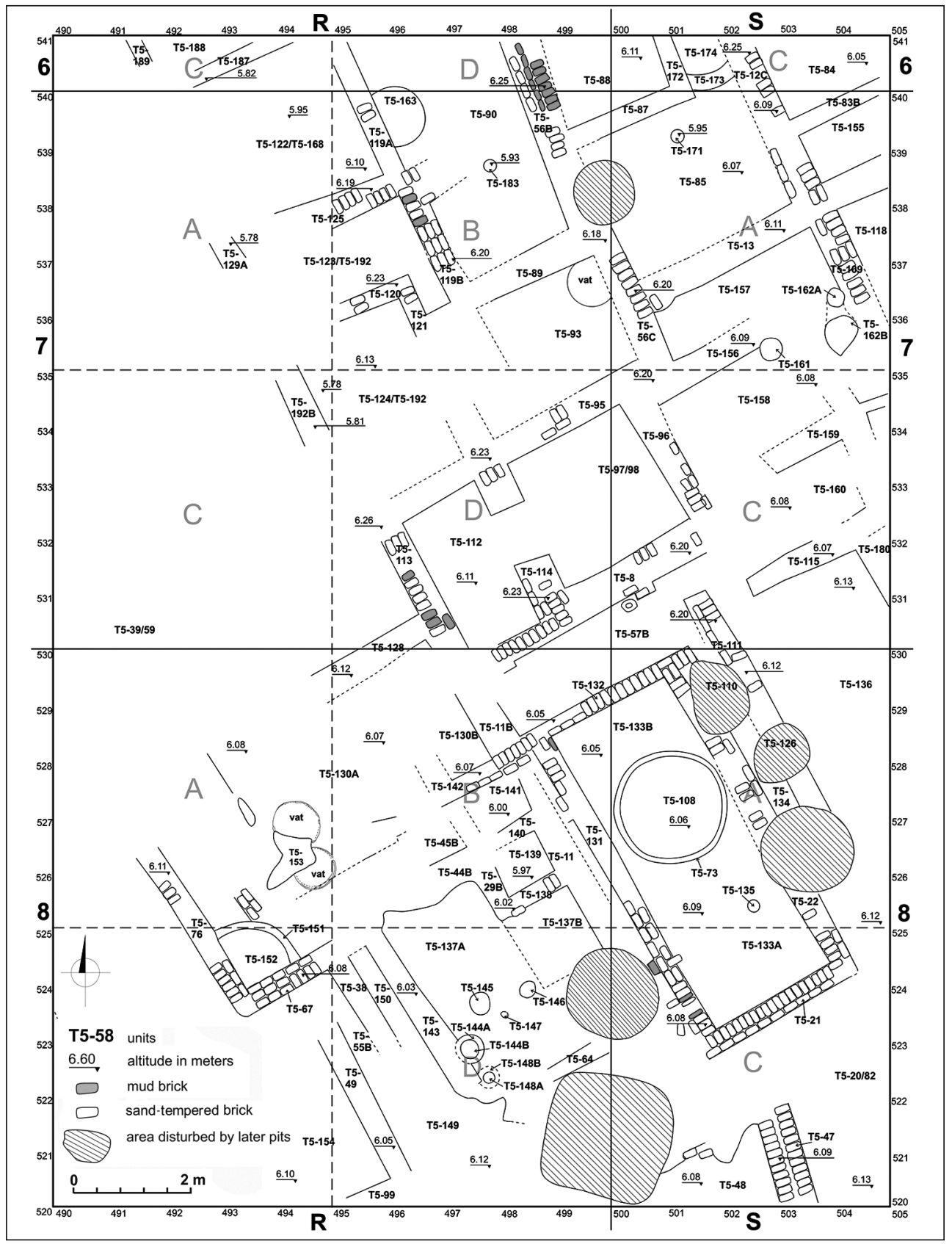

Fig. 3. Trench T5. Settlement structures. Early Old Kingdom (Third-Fourth Dynasties). Levels 15-19 (Tell el-Murra Expedition Archive/digitizing N. Matecka-Drozd) 


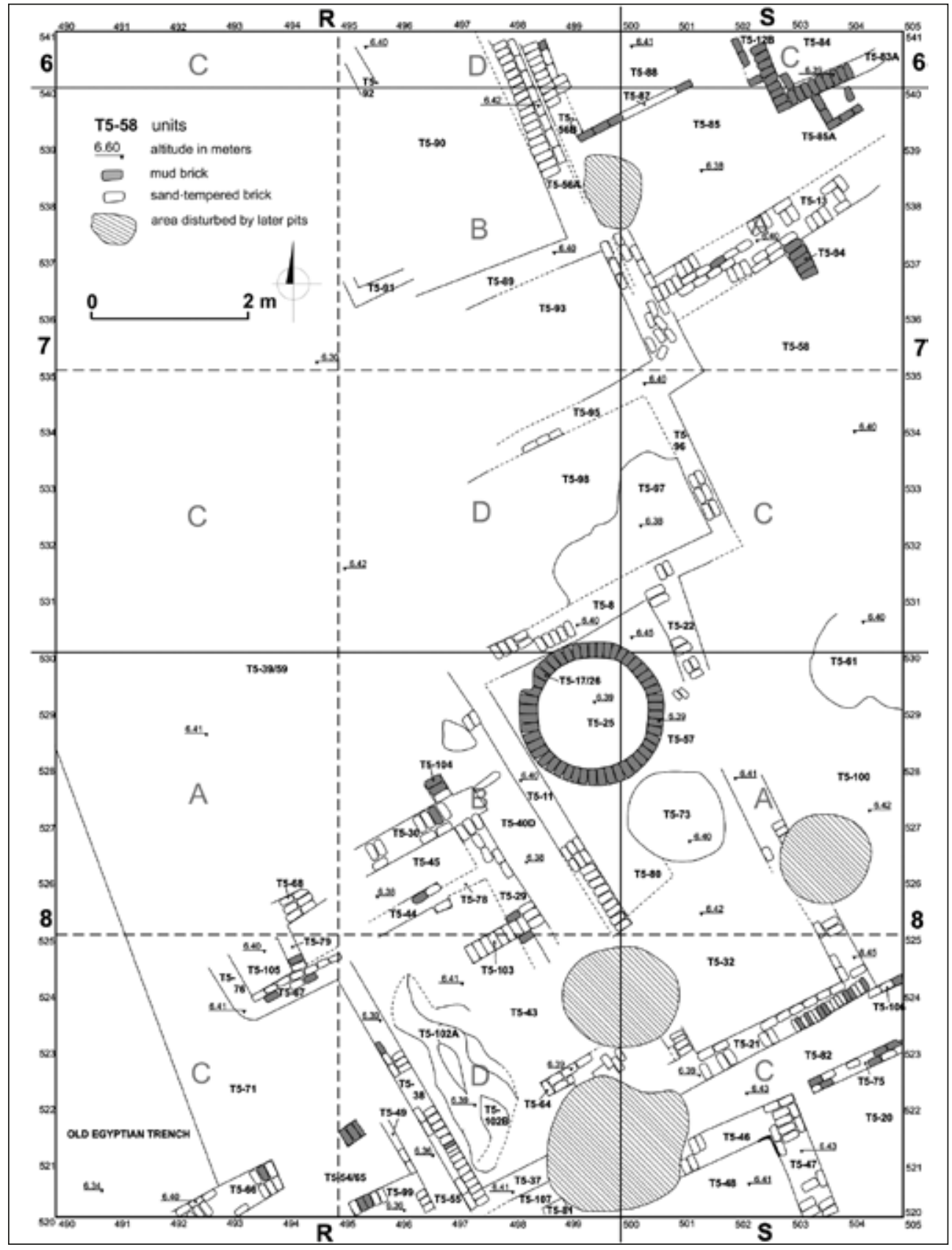

Fig. 4. Trench T5. Settlement structures. Early Old Kingdom (Third-Fourth Dynasties). Level 13 (Tell el-Murra Expedition Archive/digitizing N. Matecka-Drozd) 
and T5-22, of which the latter two were also associated with the older courtyard [see Fig. 3]. A silo (T5-17/26/T5-25) was located at the northern end. Directly south of the silo, there was a spot of dark, grey mud (T5-73), which turned out after further exploration to be a kind of pit with a mud encasement. Compartment T5-43 was situated to the southwest of corridor T5-40D. A quite extensive but shallow layer of burnt soil and ash pits (T5-102A/ T5-102B) was recognized in its western part. The southeastern corner was disturbed by a storage pit of the late Old Kingdom (T5-6A/T5-6B). The eastern end of the room was divided into three zones by short walls (T5-64 and T5-103), perpendicular to the wall (T5-29), which separated the room from the corridor. The disturbed stratigraphy around pit T5-50/ T5-63 made it impossible to determine whether an entrance existed in the latter wall. At any rate, the described room was undoubtedly approached through a corridor (T5-45) situated to the northwest. Its walls (T5-44, T5-30) were disturbed by a pit (T5-72) with animal bones. Doorways, marked by brick thresholds (T5-78 and T5-79), were identified within the corridor. The former one (T5-78) gave direct access to room $\mathrm{T} 5-43$.

Buildings in southeastern and southwestern parts of the trench

The southern fringe of trench $\mathrm{T} 5$ at Levels 13-17 (altitude 6.50-6.00 m) was occupied by structures oriented on an axis slightly shifted to the east with respect to the above-described building complex. The structures were separated from it by narrow lanes (T5-55, T5-107, T5-82) [see Fig. 4]. A probable building (walls T5-66, T5-49 and T5-99) was recognized but not investigated extensively in the southwestern part of the trench, whereas the structure in the southeastern part consisted of a room (T5-48) with two walls (T5-46 and T5-47) forming a corner. It continued to the south under the unexplored area and might be somehow related to structures discovered in test trench $S 1$ explored during the 2010 season (Jucha et al. 2013: 108-109, Fig. 3). Its north wall (T5-46) was disturbed by a storage pit of the late Old Kingdom (T5-6A/T5-6B).

\section{Pottery and small objects}

Judging by the structures, encompassing storage pits, silos, and fireplaces, as well as by the nature of the finds, the investigated area seems to have been related to agricultural activity. The pottery is numerous and several pots could be fully reconstructed. The range of forms was standard, associated with the early Old Kingdom (Third and Fourth Dynasties), although some of these forms started to occur already at the end of the Early Dynastic period.

A significant group consisted of various kinds of bowls, plates and trays. Many fragments belonged to bowls with convex sides and simple or lip-rims [Fig. 6:7,8]. Spouted bowls [Fig. 6:9] were fairly frequent, too. An alleged funnel is rather exceptional [Fig. 6:10]. Bowls with convex sides and angular inner rim edge occurred sporadically [Fig. 6:11]. Other vessel types included plates, usually with an incised line or lines on the outer surface, just below the rim [Fig. 6:12,13]. The fabric in all these cases was a fine or medium-coarse Nile clay, tempered with fine to medium-grain sand and straw. Most of the vessels are light red, red or reddish-brown coated, both inside and outside, with surfaces either polished or burnished. In the case of plates, 
which could be also made of a mediumcoarse Nile clay, only the interior surface was slipped with a red coat and polished or burnished, while the outer surface was usually uncoated and smoothed.

Meidum bowls, typical of the early Old Kingdom, consisted of forms with a maximum diameter at the height of the shoulder. Most such sherds have angular shoulders and well-developed necks
[Fig. 6:14], that is, type A3 according to Op de Beeck (2004: 270, Figs 10.3:16,22). Bowls with a maximum diameter at the rounded shoulder and angular transition between the rim and the shoulder [Fig. 6:15,16], that is, type B3b according to Op de Beeck (2004: 263, 269, Fig. 10), were rather occasional. Both these types are dated to the early part of the Old Kingdom and even the Early Dynastic Period (First-
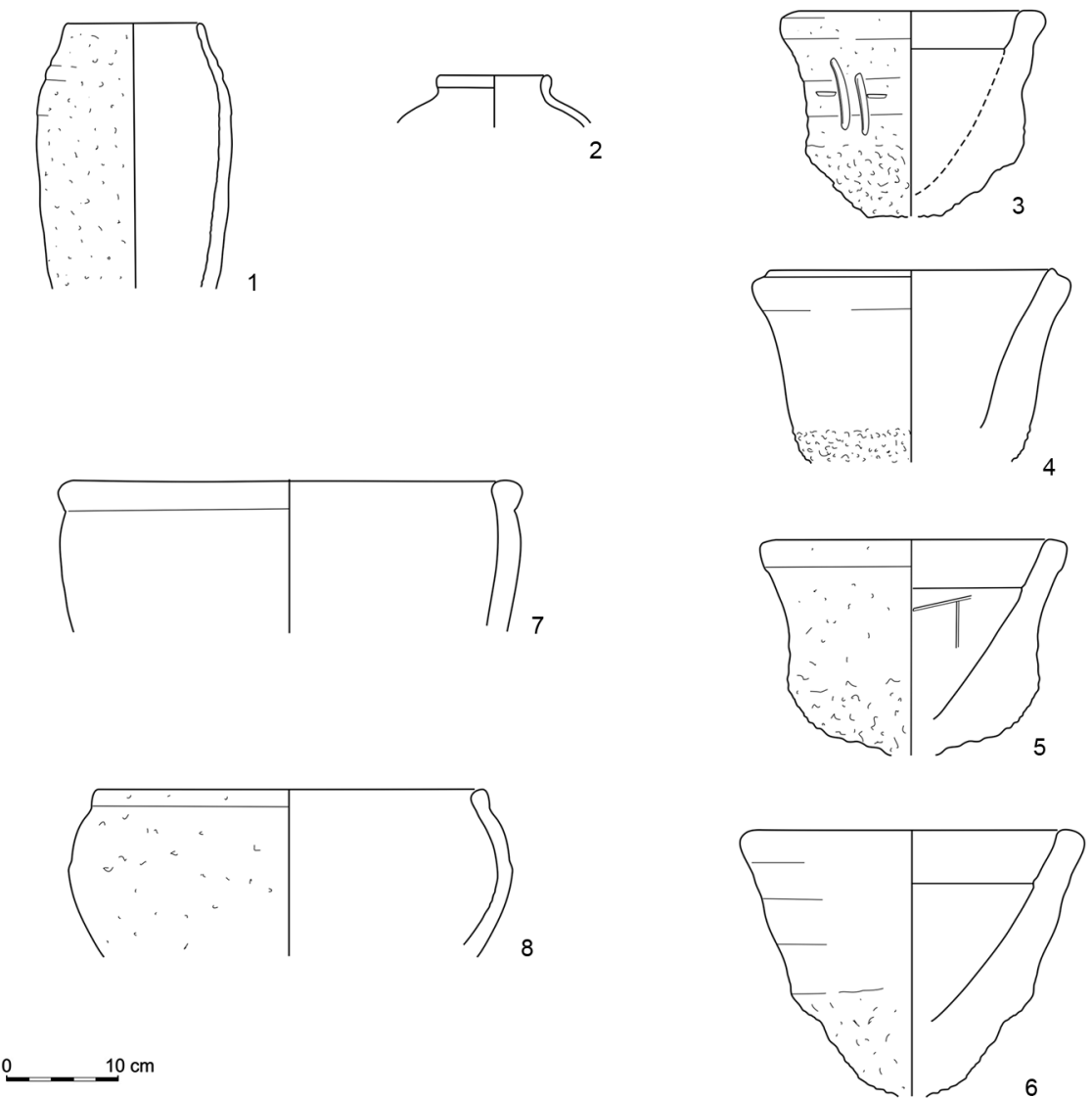

Fig. 5. Trench T5. Pottery from the settlement. Early Old Kingdom: Third-Fourth Dynasties (Tell el-Murra Expedition Archive/digitizing U. Bak) 
Second Dynasties), but could occur sporadically also in the Sixth Dynasty (Opde Beeck 2004: 263, 268-269, Fig. 10).

Rough ware bowls with an internal ledge [Fig. 6:17] were also frequent as were miniature bowls with a distinct base and simple rim [Fig. 6:18], and shallow trays with a flat base [Fig. 6:19]. They were made of medium Nile clay and their surface was usually rough and in some cases only slightly smoothed.

Another numerous group of pottery consisted of different types of jars, among them rough-ware beer jars with collars (Jucha et al. 2016: Fig. 47:2,3) or with direct rims [Fig. 5:1], rounded bases

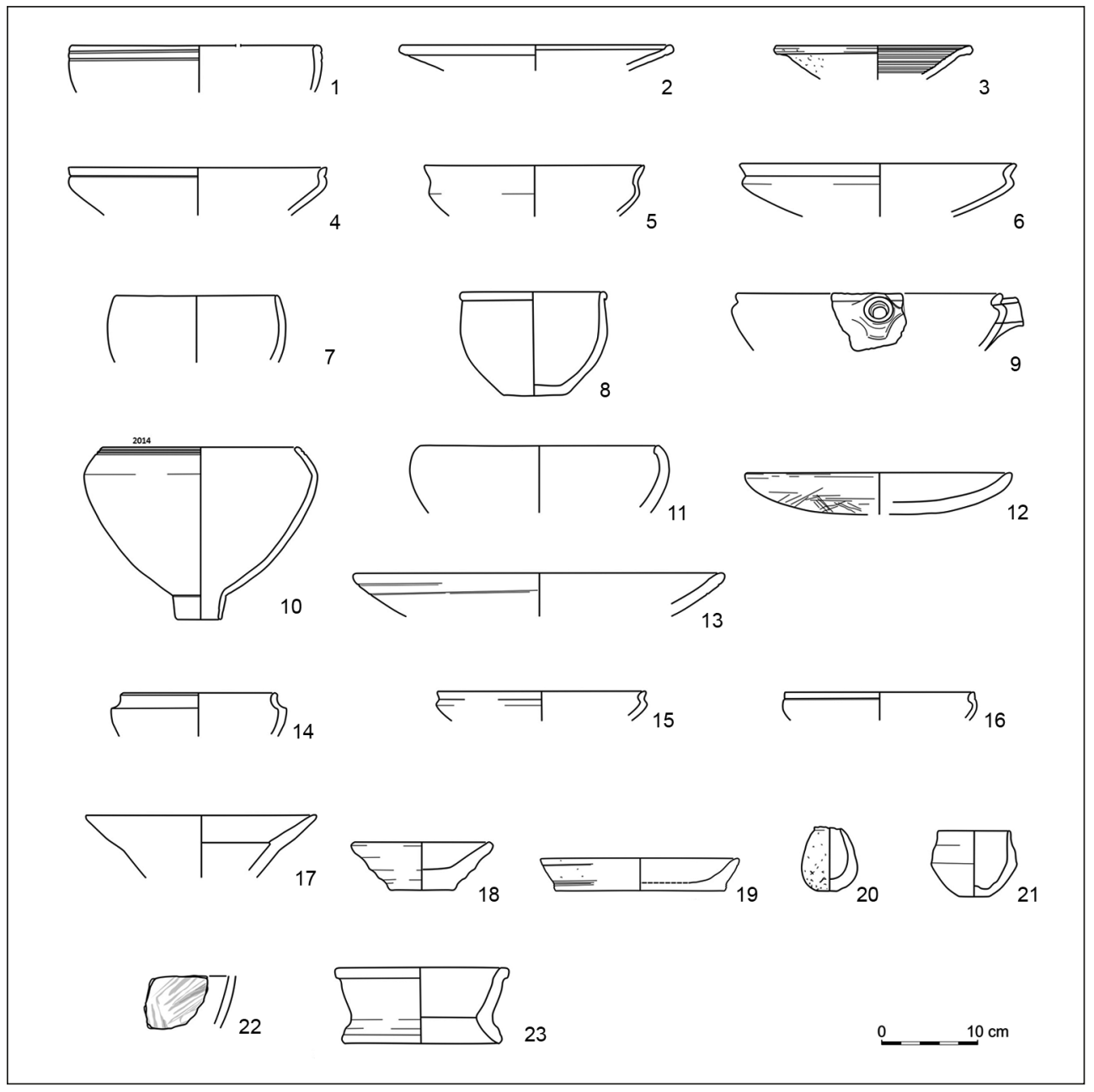

Fig. 6. Trench T5. Pottery from the settlement. 1-6 - Late Old Kingdom, Fifth-Sixth Dynasties; 7-23 - Early Old Kingdom, Third-Fourth Dynasties (Tell el-Murra Expedition Archivel digitizing U.Bak) 
and usually only slightly distinguished shoulders. Fragments of probably ovoid jars, with lip-rims and developed but usually short necks [Fig. 5:2], were also found. These were usually made of fine or medium Nile clay, and their surface was rough, sometimes slightly smoothed in the upper part of the vessels (rim and neck).

Different types of bread moulds formed an extremely large group [Fig. 5:4-6]. Most of them had an angular transition dividing the body into two zones. The upper part of the outer surface and the inner surface were slightly smoothed and the lower part of the outer surface (with a rounded base) was rough and irregularly formed. Among the forms there are examples with flattened, concave, or rounded rims, as well as a diagonal and flattened outer part of the rim. The internal part of the rim in most of the bread moulds is thickened: ${ }^{1}$ type A1, according to Jacquet-Gordon (1981: 11-12, Figs 1-3). A few almost completely preserved examples show that the Old Kingdom bread moulds were quite deep, unlike the slightly shallower examples of bread moulds typical of the Early Dynastic period. Additionally, some of the bread moulds from Tell el-Murra bear pot-marks, which were placed on the outer or inner walls of the vessels. Bread moulds collected from trench $\mathrm{T} 5$ were made of mediumcoarse or coarse Nile clay, tempered with large amounts of sand, rounded quartz and straw.

Large vats (or dough-mixing basins) [Fig. 5:7,8] and large bowls were also found in the described levels. These include fragments and almost complete examples.
They usually have thickened rounded rims, convex sides and flat bases. They were made of very coarse Nile clay tempered with large amounts of straw and sand, and their usually irregular surface was covered with some kind of red or yellow wash.

The results of pottery analysis lead to the conclusion that activities within the described structures were connected mostly with food production and consumption. The large number of bread moulds, among others, related to the layers of ashes and pits of strongly burnt soil, may suggest baking activities in some rooms (i.e., T5-43, T5-48 and, especially, T5-97/98; see Fig. 2). Two vats, brought out from the lowest strata, could have been used in the process of breadmaking, and fulfilled simple storage functions. A number of millstones and grinders provided evidence that grain stored in local silos or storage pits was milled into flour on the spot.

Flints make for yet another numerous category, including mostly sickle blades, although several knives and their fragments were attested as well. Object location is in this case significant: many flints were found within room or courtyard T5-90, but none within the adjacent room T5-93 [Fig. 3].

Personal adornments, among them a few faience and bone beads, two fragments of stone bracelets and two copper pins, were noted as well. Several stone objects, probably tools, were found all in one place in the lower strata in room T5-139. Another interesting find is a faience baboon head.

1 Similar examples also occur at Saqqara (Emery 1954: 160, Fig. 222: EE1), Buto (Köhler 1998), Elephantine (Raue 1999: 174-175, Fig. 34: 3). At Tell el-Farkha they are found in phase 6 and especially 7 (Early Dynastic and beginning of the Old Kingdom period), see Jucha 2011: 962-963, 965-966, 968-969, Figs 2:30, 3:37, 4:27. 


\section{Settlement structures}

LATE OLD KINGDOM

Remains related to the latest phase of occupation, the later part of the Old Kingdom, are very poor. These include rounded structures T5-6A/T5-6B, T5-50/T5-63 and T5-51/T5-62, the exploration of which had already started in 2013 (Jucha, Bąk-Pryc, and Małecka-Drozd 2015: 209; Jucha et al. 2016: Fig. 24). These were shaped as fairly deep pits with thin (approximately $10 \mathrm{~cm}$ ) encasements of grey, greasy mud. In the case of T5-50/ T5-63, the pit was about $0.70 \mathrm{~m}$ deep. T5$51 / \mathrm{T} 5-62$ is believed to be only slightly deeper. Its mud encasement started to vanish at the same level as the bottom of the previous pit and its filling became less visible. The third structure, T5-6A/T5-6B, had changed its shape from irregular, almost circular, into square with rounded corners. This pit, the biggest one, appears to continue down into deeper levels.

In all probability, these structures shared common storage functions, as was confirmed for similar pits found in Edfu and dated to the Old Kingdom (Moeller and Marouard 2013). However, in the present state of research, their intended use remains unclear. One clue could be the presence of spouted bowls within one of the pits (T5-63). Such vessels may have been used for beer or grain distribution
(Hendrickx et al. 2002: 292; Wodzińska 2009: 211-212). If so, their presence may suggest some kind of food production in this part of the settlement.

\section{Pottery}

The said chronology of settlement remains was confirmed by the presence of pottery vessel forms from the later part of the Old Kingdom (Fifth and Sixth Dynasties). These included bowls with parallel lines or ribs situated on the outer surface just below the rim [Fig. 6:1] and bowls with a rounded inner and outer part of the rim [Fig. 6:2]. Both types are quite frequent. Also a few fragments of bowls with incised parallel lines on the inner surface were registered [Fig. 6:3]. Among Meidum bowls, which were found in significant quantities, several types typical of the Fifth and Sixth Dynasties were distinguished (Kazimierczak 2014a): bowls with the same diameter at the rim and the shoulder as well as a short neck and an angular transition from the shoulder to the rim [Fig. 6:4], type B1b1 after Op de Beeck (2004: 263, 269, Fig. 10); bowls with a greater diameter at the rim than at a rounded shoulder and with the rim curved outwards [Fig. 6:5], type B2a according to Op de Beeck (2004: 263, 269, Fig. 10); and bowls with a rounded shoulder and a clear line below the rim [Fig. 6:6], Op de Beeck's type B2b (2004: 263, 269, Fig. 10).

\section{TRENCH S3}

The research in the southwestern part of the tell conducted in seasons 2014-2015 was a continuation of the work initiated there in 2008. The count of tombs explored between 2011 and 2015 stands at 30, including 16 in the two reported seasons. There can be no doubt that at least during the Naqada III-Early Dynastic period the area functioned as a cemetery. Settlement remains were also recorded.

Six of the graves explored during the reported seasons were found in are J22, where most of the graves excavated previously were also located (Jucha, Bąk- 
-Pryc, and Czarnowicz 2014: 143-146, Figs 2-4; Jucha, Bąk-Pryc, and MałeckaDrozd 2015: 200-208, Figs 2-4, 7-9; Jucha et al. 2016: Fig. 3). Grave 23 [Fig. 7 left] in the northwestern part of the square disturbed mud-brick wall S3-57 of an older structure of still uncertain function (Jucha, Bąk-Pryc, and Małecka-Drozd 2015: 200, Fig. 2). The rectangular burial chamber, lined with distinct light sand-colored side walls of cohesive consistency, had an external size of $1.50 \mathrm{~m}$ by $1.00 \mathrm{~m}$. The burial goods, placed beside a pottery coffin, included five ceramic vessels: two beer jars, a bowl with convex sides, a plate [Fig. 11:5] and a miniature bowl [Fig. 11:4].

Grave 8 [Fig. 7 right] was located further to the south, between the previously explored graves 5 and 9 (Jucha, Bąk-Pryc, and Małecka-Drozd 2015: 201-203, 207, Figs 2, 4, 5, 8, 9: bottom left). The rectangular burial pit, $1.45 \mathrm{~m}$ by $1.00 \mathrm{~m}$ in size, contained only one jar [Fig. 11:9]. Grave 25 further to the east also had a rectangular burial pit, only $1.05 \mathrm{~m}$ by $0.80 \mathrm{~m}$ in size, and did not contain any grave goods. To the east were three other graves, partly disturbed by Grave 2. Grave 22 of almost rectangular shape, $1.00 \mathrm{~m}$ by $0.60 \mathrm{~m}$, and Grave 24 [Fig. 8 top], which measured $0.75 \mathrm{~m}$ by $0.45 \mathrm{~m}$. Neither contained any pottery or stone vessels, but in the latter case there were two bracelets made of greywacke on the right forearm of the deceased. Grave 24 also disturbed mud-brick wall S3-19 to the west, possibly the remains of a settlement structure of an older date. The third, Grave 20 [Fig. 8 bottom], was rectangular in shape, $1.65 \mathrm{~m}$

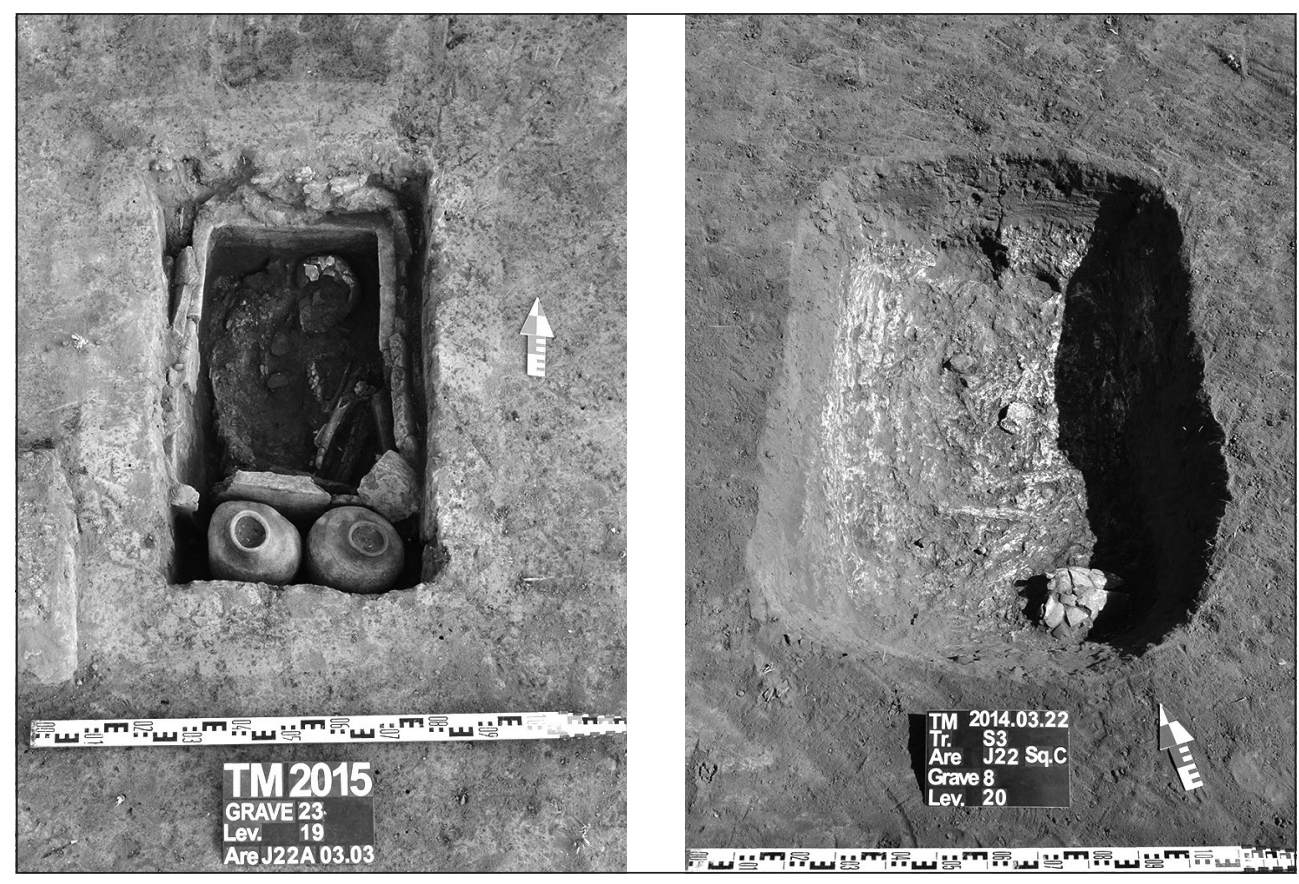

Fig. 7. Burials in trench S3: left, Grave 23; right, Grave 8 (Tell el-Murra Expedition Archive/photos G. Bąk-Pryc) 

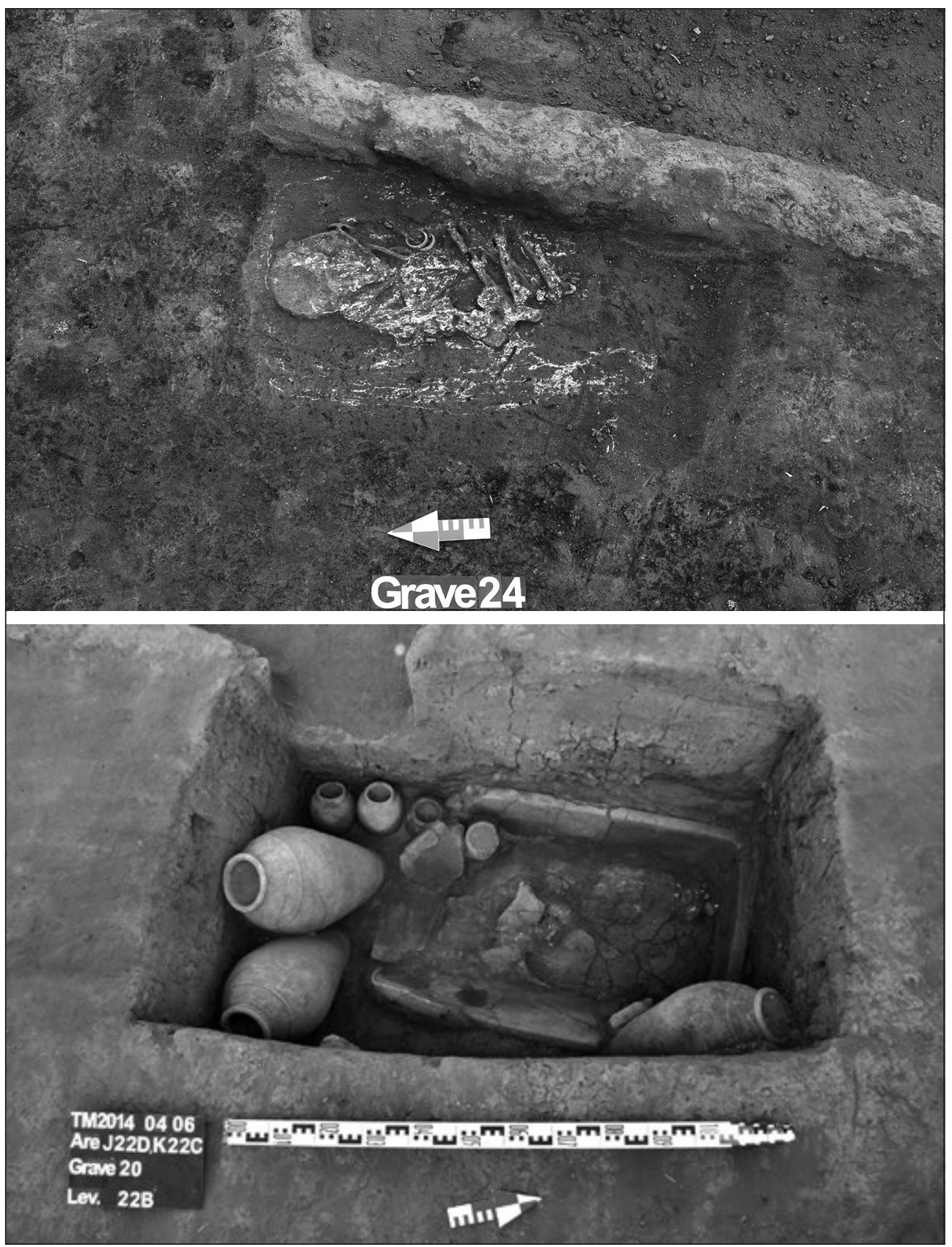

Fig. 8. Burials in trench S3: top, Grave 24; bottom, Grave 20

(Tell el-Murra Expedition Archive/photos G. Bąk-Pryc, E. Kuciewicz) 
by $1.05 \mathrm{~m}$, and contained, among others, a travertine cylindrical jar with engraved sign and a miniature rectangular cosmetic palette made of greywacke, both found inside the pottery coffin. Seven ceramic vessels were placed inside the burial pit. These included three large wine jars [Fig. 11:12], each with two rope bands, a barrel-shaped jar [Fig. 11:13], two smaller broad-shouldered jars [Fig. 11:14] and a plate [Fig. 11:11].

Two more graves were discovered in the southwestern part of the trench, in squares J23A and J23B, the first of the two already known to be densely filled with burials (Jucha et al. 2016: Fig. 3). Grave 30 was located between Graves 12 and 18 explored already in 2013 (Jucha, Bąk-Pryc, and Małecka-Drozd 2015: 205-208, Figs 8, 9: top right and bottom right). The outline of the burial pit had a poorly defined external borderline. However, it seems to be oval in shape and measured around $0.80 \mathrm{~m}$ by $0.50 \mathrm{~m}$. Only one small pottery jar [Fig. 11:8] made up the burial goods. Grave 19 further to the southeast had a rectangular burial pit with rounded corners, $1.20 \mathrm{~m}$ by $0.80 \mathrm{~m}$ in size [Fig. 9 left]. The northwestern corner of the grave disturbed wall S3-167, which was aligned NE-SW and was possibly related to an older settlement structure, traced already during the previous season (Jucha, Bąk-Pryc, and Małecka-Drozd 2015: 207). The burial goods comprised five ceramic vessels. These included a broad-shouldered beer jar [Fig. 11:18], a small broadshouldered jar [Fig. 11:17], a wine jar with a rope band on the shoulder [Fig. 11:19], a bowl with convex sides [Fig. 11:15] and a plate [Fig. 11:16].

Four more graves were explored in the southeastern part of the trench, in squares K23A and К23в. Grave 21 [Fig. 9 right] was located to the east of Grave

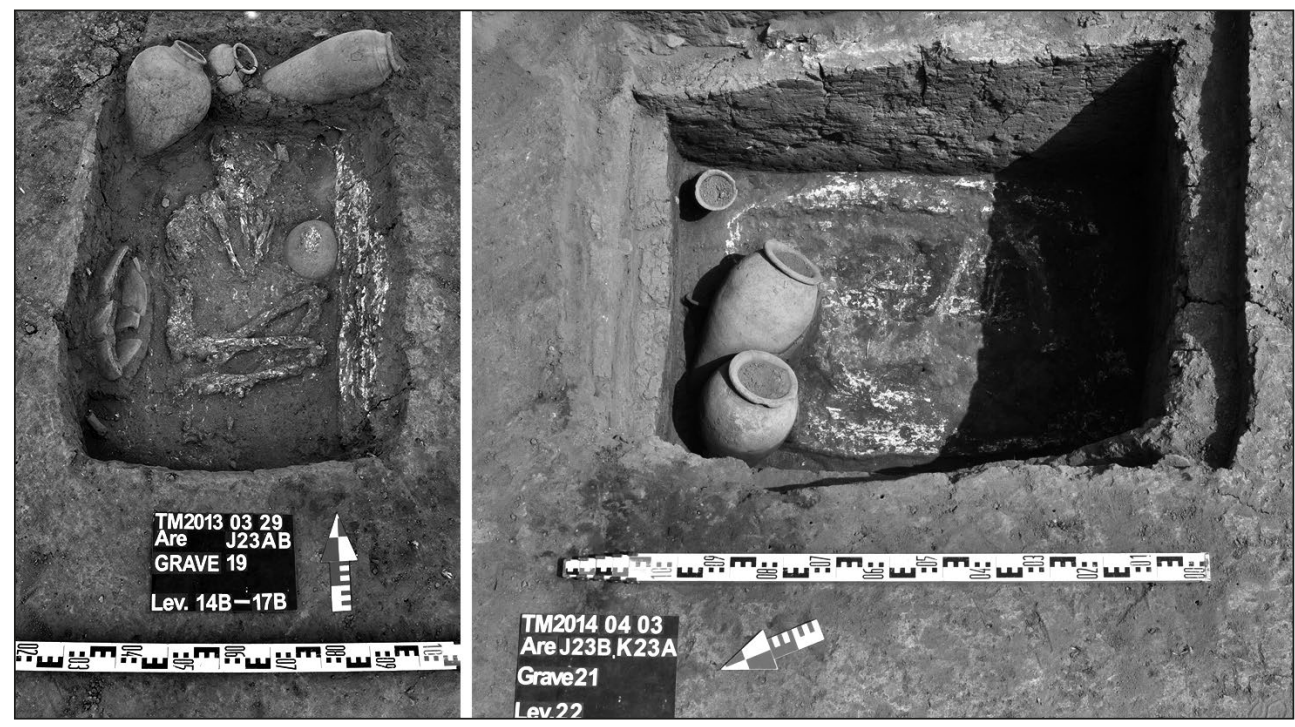

Fig. 9. Burials in trench S3: left, Grave 19; right, Grave 21

(Tell el-Murra Expedition Archive/photos G. Back-Pryc, E. Kuciewicz) 


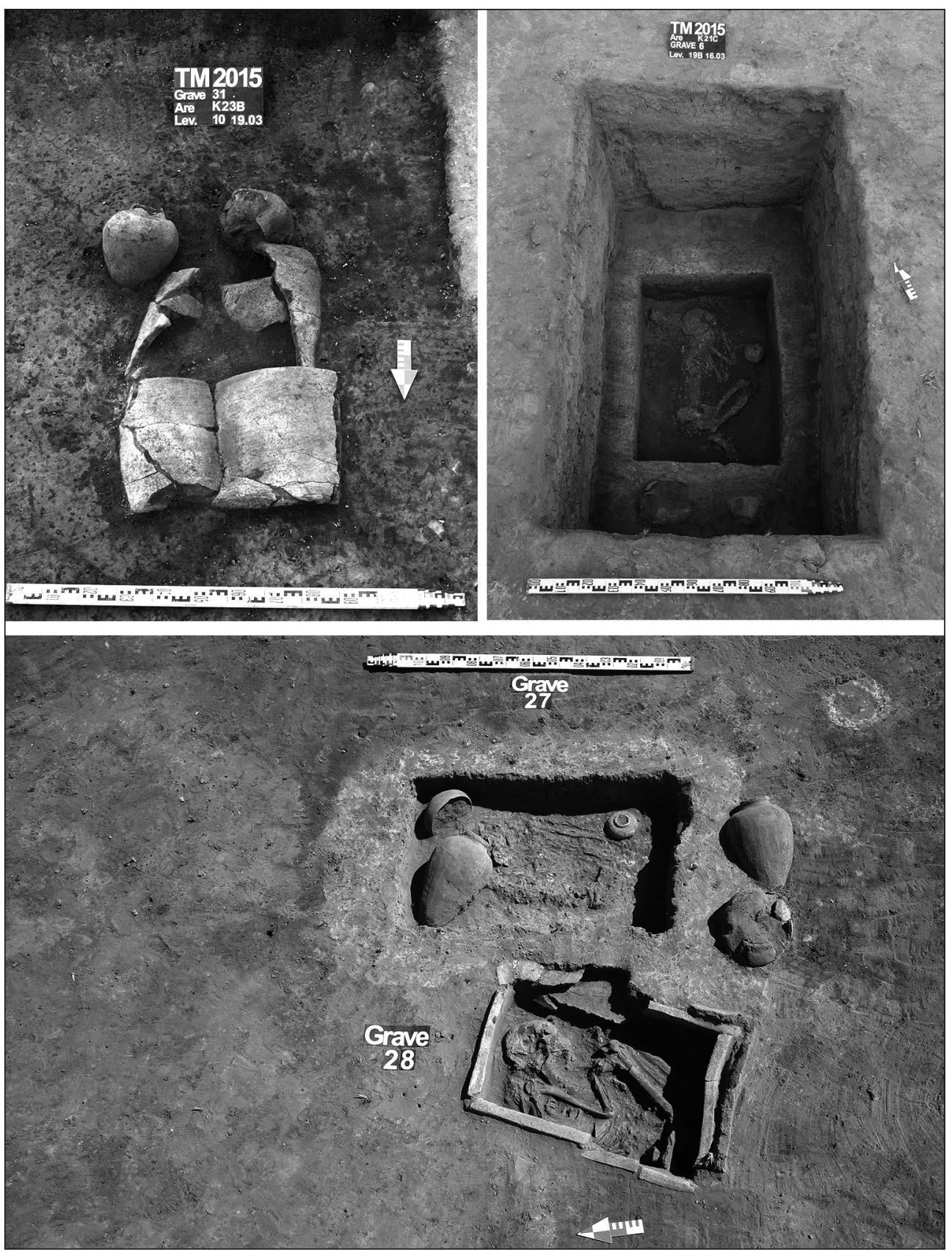

Fig. 10. Burials in trench S3: top left, Grave 31; top right, Grave 6; bottom, Graves 27 and 28 (Tell el-Murra Expedition Archive/photos G. Bak-Pryc, E. Kuciewicz) 


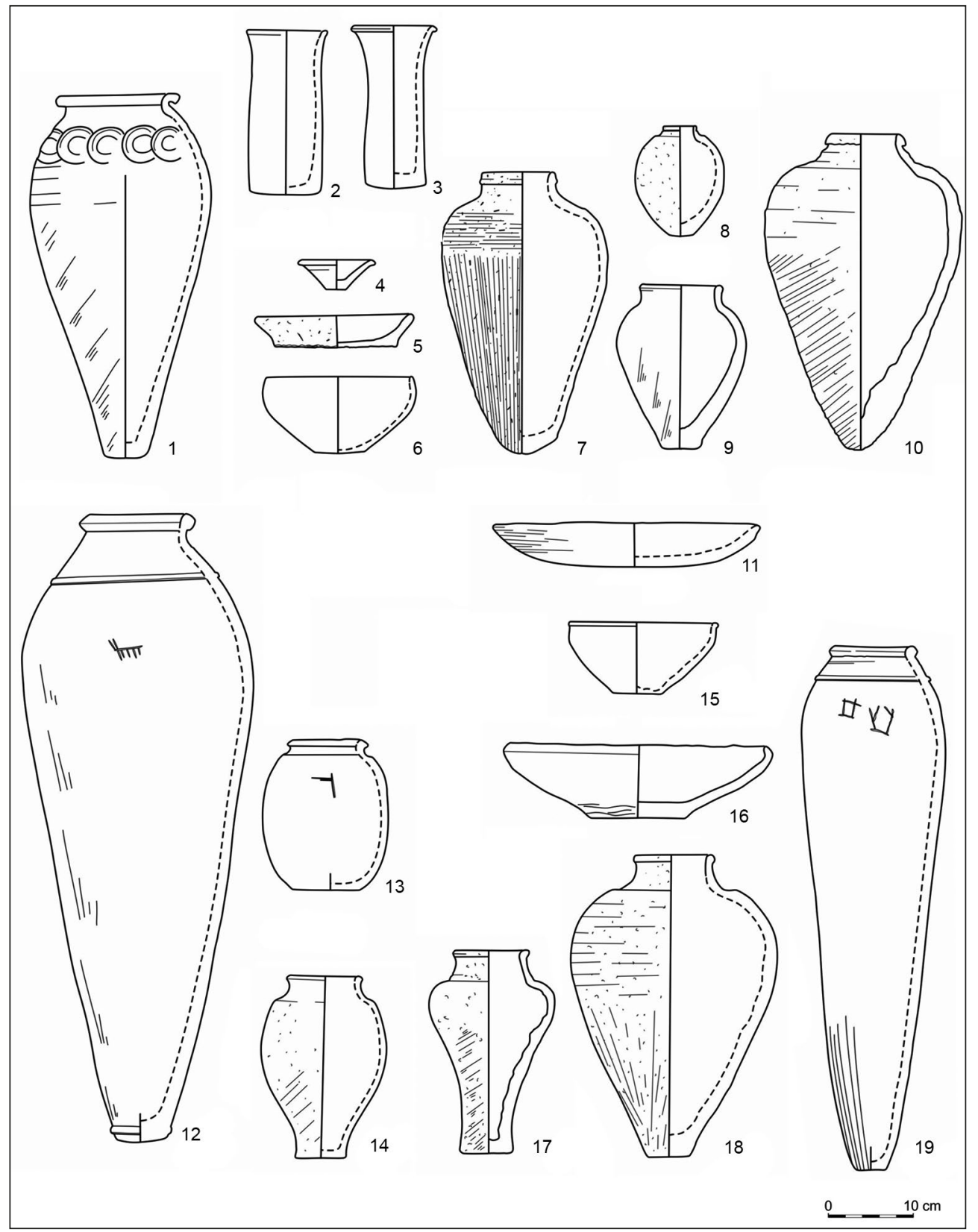

Fig. 11. Pottery from the graves in trench S3: 1-3 - Grave 21; 4-5 - Grave 23; 6-7 - Grave 27; 8 Grave 30; 9 - Grave 8; 10 - Grave 6; 11-14-Grave 20;15-19 - Grave 19 (Tell el-Murra Expedition Archive/digitizing U. Bąk) 
19. The rectangular burial pit was $1.20 \mathrm{~m}$ by $0.85 \mathrm{~m}$ in size. To the south, the grave adjoined a wall of mud brick (S3-201). Five ceramic vessels were placed in the grave. These included two fairly elongated jars [Fig. 11:1], two undecorated cylindrical jars [Fig. 11:2,3] and a bowl with convex sides. The burial goods also contained three copper items: two harpoons and one adze. To the east was Grave 31 [Fig. 10 top left], a shallow rectangular-like burial pit, $1.00 \mathrm{~m}$ by $0.70 \mathrm{~m}$ in size, containing a pottery coffin. Two beer jars were also associated with the burial. Grave 26, located in the proximity of the previous one on its eastern side, was characterized by a poorly defined external borderline and an oval-like shape. It was $0.80 \mathrm{~m}$ by $0.45 \mathrm{~m}$ in size. Grave 32 was found slightly to the northeast. The poorly defined burial pit was approximately $0.80 \mathrm{~m}$ by $0.60 \mathrm{~m}$ in size. Neither of the latter two graves contained any grave goods.

Four more graves were situated in the northeastern part of the trench (squares K22A, K21C and K21D). Grave 29, situated on the spot of a round settlement structure, considered to be a silo (S3-47/ S3-88) (Jucha, Bąk-Pryc, and MałeckaDrozd 2015: 203-204, Figs 6, 7) is the sole burial known so far from square K22A. The oval-like burial pit was $0.80 \mathrm{~m}$ by $0.50 \mathrm{~m}$ in size. Burial goods consisted of one smallsized flat bowl made of greywacke. Grave 6 to the north [Fig. 10 top right] (square K21C) was first apparent in 2012 as an outline of the superstructure (S3-92/ S3-77) to the east of the then explored Grave 7 (Jucha, Bąk-Pryc, and Małecka-Drozd 2015: 204-205, Figs 7, 9: top left). Its external size proved to be $2.65 \mathrm{~m}$ by $1.80 \mathrm{~m}$. A rectangular burial chamber was constructed at the bottom of a pit below the superstructure. Its size between the external edges was $1.60 \mathrm{~m}$ by $1.20 \mathrm{~m}$. The grave assemblage included two pottery jars [Fig. 11:10] and two stone vessels, a slender jar and a squat one. Two other graves, 27 and 28 [Fig. 10 bottom], adjoining each other, were located to the east of Grave 6 (square K21D). The burial chamber of Grave 27 was rectangular in shape, $1.45 \mathrm{~m}$ by $1.00 \mathrm{~m}$ in size, formed of light sandcolored side walls of cohesive consistency. The burial goods comprised a small squat travertine jar and four ceramic vessels. The latter included three beer jars [Fig. 11:7] and a bowl with convex sides [Fig.11:6]. Grave 28 adjoined Grave 27 from the west. The outside measurements of the rectangular burial pit containing a pottery coffin were $1.00 \mathrm{~m}$ by $0.70 \mathrm{~m}$. The grave did not contain any funerary goods.

Of the described graves explored in 2014-2015, the oldest one, Grave 21, was dated to the beginning of the First Dynasty-Naqada IIIC1. Two others, Graves 22 and 24, although not containing any pottery or stone vessels, were possibly also earlier than Early Dynastic as both were partly disturbed by a later burial (Grave 2) of Naqada IIIC2 date explored in 2011 (Jucha, Bąk-Pryc, and Czarnowicz 2014: 144-145, Figs 2, 3 right, 4, 5; Kazimierczak 2014b: 110-113, Fig. 5). Two graves, 19 and 20, were dated based on the pottery to the second part of the First Dynasty (Naqada IIIC2). Grave 20 had also been disturbed by Grave 2. Thus, although they seem to be of very close chronology, Grave 20 was undoubtedly slightly older. Grave 20 seems also older than Grave 19, the latter being possibly roughly contemporary with Grave 2. The dating of another two graves, 8 and 30 , is uncertain, due to the very modest number 
of grave goods. It seems, however, that they can be placed during the First Dynasty period (Naqada IIIC). One of them, Grave 8, was partly disturbed by, among others, Grave 5 of Naqada IIID date explored in 2012 (Jucha, Bąk-Pryc, and Małecka-Drozd 2015: 201-203, Figs 2, 4, 5). Three graves (23, 27 and 31) were dated to the second half of the First Dynasty/first half of the Second Dynasty (Naqada IIIC2/D). Grave 6 also seems to be of similar chronology, as it shared the same alignment as Grave 7, which was located directly to the west and explored in 2012 (Jucha, Bąk-Pryc, and MałeckaDrozd 2015: Figs 7, 9: top left). Five graves could not be dated precisely for lack of grave goods (Graves 25, 26, 28, and 32 ) or having just one type of grave good (Grave 29). Considering, however, that no material later than the Early Dynastic period was collected from layers located above the graves in trench $S 3$, it can be assumed that these graves should be attributed to a time span covering that period.

Most of the graves shared a similar characteristic as regards grave and body orientation: alignment of the burial along a NE-SW axis, bodies in tightly contracted position, on the left side, head to the northeast (Graves 6, 8, 20, 21, 22, $28,29,30$, and 32). In six cases, burials were oriented along a $\mathrm{N}-\mathrm{S}$ axis with the body on the left side, head to the north (Graves 19, 23, 24, 25, 27, and 31). In one case (Grave 26), the orientation was NWSE. The skull was missing in this case, but the position of the skeleton suggested a tightly contracted position of the body placed on its left side with the torso to the northwest. In four cases (Graves 20, 23, 28, and 31 ), the burials were made in pottery coffins consisting of rectangular boxes with semi-cylindrical two-part lids.

Several other structures, of other than funeral purpose or of still undefined function, were also explored in trench S3. Their upper parts had been visible earlier. Some were disturbed by the later graves. The precise dating and function of these structures is in most cases still uncertain pending further exploration. At least in some cases, we may be dealing not with grave structures, but the remains of settlement structures. A mud-brick wall of NE-SW orientation in square J23B, traced from Level 13B (altitude $4.95 \mathrm{~m}$ ), may be a continuation of wall S3-34 (Jucha, Bąk-Pryc, and Czarnowicz 2014: 146, Fig. 4) found during previous seasons in square J22D to the east of Graves 2 and 20. The said wall was possibly joined to yet another mud-brick wall, S3-201, aligned NW-SE, observed from Level 13B (altitude $4.95 \mathrm{~m}$ ), in square J23B to the south of Grave 21. Another wall, S3-57 (Jucha, Bąk-Pryc, and Małecka-Drozd 2015: 200, Fig. 2), traced already in 2012 in the northern part of square J22A, to the north of Grave 3, was still visible in the lower levels (Level 16, altitude $4.70 \mathrm{~m}$ ) explored later. It was ruined from the east by the later Grave 23 . Structure S3-163 was located already in 2013 in square J23 A, to the east of Grave 17 (Jucha, Bąk-Pryc, and Małecka-Drozd 2015: 207) and south of Grave 19. Below that structure, the outline of unit S3-257 was recorded but not explored in 2015 at Level 16, altitude $4.70 \mathrm{~m}$. 


\section{TRENCH S3B}

Work continued in trench S3B in the southwestern part of the tell. The trench, $5 \mathrm{~m}$ by $5 \mathrm{~m}$, had been explored already in 2012 (Jucha, Bąk-Pryc, and Małecka-Drozd 2015: 208). In the 2014 and 2015 seasons, Levels 21-29 (altitude $4.20 \mathrm{~m}$ to $3.40 \mathrm{~m}$ ), and $30-39$ (altitude $3.30 \mathrm{~m}$ to $2.40 \mathrm{~m}$ ) were explored successively.

Wall S3-135, the top of which was recorded in Level 18, altitude $4.50 \mathrm{~m}$, in 2012 (Jucha, Bąk-Pryc, and Małecka-Drozd 2015: 208) turned out to reach down to Level 22 (altitude $4.10 \mathrm{~m}$ ). To the north of it was a brown clayey layer (S3175), while to the south were light-colored, cohesive layers S3-180, S3-182 and S3183. Furthermore, layers S3-176, brown and of loose consistency, and S3-177, light brown and of cohesive consistency, were identified in the eastern part of the trench to the east of the said wall. S3-179, a grey layer of loose consistency, was noted in the southeastern part of the trench. Remains of another mud-brick wall, S3-195, appeared in Level 26 (altitude $3.70 \mathrm{~m}$ ). It formed the corner of a structure aligned NE-SW, continuing to the south and east beyond the trench. A light brown and loose layer (S3-194) with a limited number of potsherds was found inside of this wall corner. The structure continued until Level 31 (altitude $3.20 \mathrm{~m}$ ). However, remains of several additional walls were distinguished during further exploration. These included mud-brick wall S3-223, joined from the north with the western part of the wall S3-195. Another mud-brick wall (S3-228), distinguished inside the building at Level 31 but further to the south, adjoined wall
S3-195 perpendicularly from the east. The assumed continuation of wall S3-228 to the east was ruined by a mud-filled and cohesive layer, S3-227, and a brown loose layer, S3-241. The said wall divided the inside of the structure into two parts, the northern, S3-225/S3-226, and southern S3-236. A hearth, S3-224, was discovered in the northern one. It was filled with a dark brown layer with traces of burning. The archaeological material from these levels included mainly potsherds, flint tools and animal bones. The pottery was mostly of Naqada III chronology.

The levels located below Level 32 (altitude $3.10 \mathrm{~m}$ ), where the bottom of the structure was situated, did not contain any distinct walls or other architectural remains. The archaeological material was also very scarce. The same is true of Level 39 (altitude $2.40 \mathrm{~m}$ ), the last one explored in the 2015 season, where a dark-colored and highly cohesive layer (S3-268) was noted. To the west and south, it adjoined another light-colored and cohesive layer (S3-269). The archaeological material, if present, comprised mostly potsherds, apparently still of Naqada III date. Other finds included flint tools and animal bones.

Layers possibly related to alluvial deposits resulting from natural causes, like high water levels during periodic floods, were also distinguished within the trench. They were represented in the section as layers, mostly grey in color and of a cohesive consistency. These layers were in general devoid of archaeological material or else finds were very scarce compared to layers associated with architectural structures. 
Dr. Mariusz A. Jucha

Institute of Archaeology, Jagiellonian University in Kraków

31-007 Kraków, Poland, ul. Gołębia 11

m.jucha@murra.pl

Grzegorz Bąk-Pryc

PhD candidate, Institute of Archaeology, Jagiellonian University in Kraków

31-007 Kraków, Poland, ul. Gołębia 11

grzegorz.pryc@uj.edu.pl

Natalia Małecka-Drozd

PhD candidate, Institute of Archaeology, Jagiellonian University in Kraków

31-007 Kraków, Poland, ul. Gołębia 11

nbmalecka@gmail.com

Magdalena Kazimierczak

PhD candidate, Institute of Archaeology, Jagiellonian University in Kraków

31-007 Kraków, Poland, ul. Gołębia 11

magdakazimierczak@poczta.onet.pl

\section{REFERENCES}

Adams, M.J. (2009). An interim report on the Naqada III - First Intermediate Period stratifications at Mendes 1999-2005. In D.B. Redford (ed.), Delta reports (Research in Lower Egypt) I (pp. 121-206). Oxford: Oxbow Books

Badawy, A. (1954). A history of Egyptian architecture I. From the earliest times to the end of the Old Kingdom. Giza: A. Badawy

Emery, W.B. (1954). Great tombs of the First Dynasty: Excavations at Sakkara II [=EES Excavation Memoirs 46]. London: Egypt Exploration Society

Hendrickx, S., Faltings, D., Op de Beeck, A., Raue, D., and Michiels, C. (2002). Milk, beer and bread technology during the Early Dynastic period. MDAIK, 58, 277-304

Jacquet-Gordon, H. (1981). A tentative typology of Egyptian bread moulds. In D. Arnold (ed.), Studien zur altägyptischen Keramik (pp. 11-24). Mainz am Rhein: Philipp von Zabern

Jucha, M.A. (2009). The north-eastern part of the Nile Delta - Research perspectives. Polish archaeological survey in the Ash-Sharqiyyah Governorate. In J. Popielska-Grzybowska and J. Iwaszczuk (eds), Proceedings of the Fifth Central European Conference of Young Egyptologists: Egypt 2009. Perspectives of research, Puttusk 22-24 June 2009 [=Acta Archaeologica Pultuskiensia 2] (pp. 83-88). Pultusk: Pułtusk Academy of Humanities

Jucha, M.A. (2010). Tell el-Murra. The Predynastic north-eastern Nile Delta. Folia Orientalia, 47, 379-390

Jucha, M.A. (2011). The development of pottery production during the Early Dynastic Period and the beginning of the Old Kingdom: A view from Tell el-Farkha. In R.F. Friedman and P.N. Fiske (eds), Egypt at its origins 3: Proceedings of the third international conference "Origin of the state. Predynastic and early dynastic Egypt", London, 27th July-1st August 2008 [=OLA 205] (pp. 953-974). Leuven: Peeters 
Jucha, M.A. and Bąk-Pryc, G. (2017). Settlement and cemetery - new research on the 4th/3rd millennium Nile Delta site at Tell el-Murra. In B. Midant-Reynes and Y. Tristant with collaboration of E.M. Ryan, Egypt at its Origins 5. Proceedings of the Fifth International Conference "Origin of the State. Predynastic and Early Dynastic Egypt". Cairo, 13th-18th April 2014 [=OLA 260] (pp. 175-197). Leuven-Paris-Bristol: Peeters

Jucha, M.A., Bąk-Pryc, G. and Czarnowicz, M. (2014). Tell el-Murra (Northeastern Nile Delta survey): season 2011. PAM, 23/1, 141-152

Jucha, M.A., Bąk-Pryc, G., and Małecka-Drozd, N. (2015). Tell el-Murra (Northeastern Nile Delta Survey). Seasons 2012-2013. PAM, 24/1, 199-214

Jucha, M.A. with contributions by G. Bąk-Pryc, N. Małecka-Drozd, M. Kazimierczak, M.F. Ownby, K. Mądrzyk, A. Pankowska, B. Woźniak, R. Abłamowicz. (2016). Polish excavations at Tell el-Murra in the Nile Delta. Preliminary report 2013-2015. Archaeologia, $65,85-146$

Jucha, M.A., Błaszczyk, K., Buszek, A., and Pryc, G. (2013). Tell el-Murra (Northeastern Nile Delta Survey). Season 2010. PAM, 22, 105-120

Jucha, M.A. and Buszek, A. (2011). Tell el-Murra (North Eastern Nile Delta Survey). Season 2008. $P A M, 20,177-182$

Kazimierczak, M. (2014a). Meidum bowls from Tell el-Murra, Trench T5 (season 2013). In M.A. Jucha, J. Dębowska-Ludwin, and P. Kołodziejczyk (eds), Aegyptus est imago caeli: Studies presented to Krzysztof M. Ciatowicz on his 60th birthday (pp. 161-166). Kraków: Institute of Archaeology, Jagiellonian University

Kazimierczak, M. (2014b). Pottery from Tell el-Murra graves. Seasons 2011-2012. SAAC, 18, 101-118

Köhler, E.C. (1998). Tell el-Fara 'în - Buto III. Die Keramik von der späten Naqada-Kultur bis zum frühen alten Reich (Schichten III bis VI) [=AV 94]. Mainz am Rhein: Philipp von Zabern

Lehner, M. (1993). Giza. In The Oriental Institute 1991-1992 annual report (pp. 56-67). Chicago: Oriental Institute of the University of Chicago

Lehner, M. (1994). Giza. In The Oriental Institute 1993-1994 annual report (pp. 26-30). Chicago: Oriental Institute of the University of Chicago

Moeller, N. and Marouard, G. (2013). Tell Edfu. In The Oriental Institute 2012-2013 annual report (pp. 113-125). Chicago: Oriental Institute of the University of Chicago

Op de Beeck, A. (2004). Possibilities and restrictions for the use of Maidum-bowls as chronological indicators. CCE, 7, 239-274

Raue, D. (1999). Ägyptische und Nubische Keramik der 1.-4. Dynastie. In W. Kaiser et al., Stadt und Tempel von Elephantine, 25./26./27. Grabungsbericht. MDAIK, 55, 173-189

Roik, E. (1988). Das altägyptische Wohnhaus und seine Darstellung im Flachbild I-II. Frankfurt am Main: P. Lang

Wodzińska, A. (2009). Domestic and funerary/sacral pottery from the Fourth Dynasty Giza. In T. Rzeuska and A. Wodzińska (eds), Studies on Old Kingdom pottery (pp. 209-224). Warsaw: Neriton 